\title{
Comparative analyses of semen and endocrine characteristics of free-living versus captive jaguars (Panthera onca)
}

\author{
R. G. Morato ${ }^{1,2}$, V. A. Conforti², F. C. Azevedo' ${ }^{2}$, A. T. A. Jacomo ${ }^{2}$, \\ L. Silveira ${ }^{2}$, D. Sana ${ }^{2}$, A. L. V. Nunes ${ }^{3}$, M. A. B. V. Guimarães ${ }^{4}$ and \\ R. C. Barnabe ${ }^{1}$ \\ ${ }^{1}$ Departamento de Reprodução Animal, Faculdade de Medicina Veterinária e Zootecnia, \\ Universidade de São Paulo, São Paulo, Brasil 05508-000; ${ }^{2}$ Associação para a Conservação \\ dos Carnívoros Neotropicais, São Paulo, Brasil 02611-001; ${ }^{3}$ Parque Zoológico Municipal \\ 'Quinzinho de Barros', Sorocaba São Paulo, Brasil; ${ }^{4}$ Fundação Parque Zoológico de São \\ Paulo, São Paulo, Brasil
}

Semen and blood samples were obtained from free-living $(n=6)$ and captive $(n=8)$ jaguars (Panthera onca) to compare reproductive characteristics between the two populations. Semen samples were analysed for volume $(\mathrm{ml})$, percentage of motile spermatozoa, rate of forward progression (0-5), concentration $\left(10^{6} \mathrm{ml}^{-1}\right)$, total sperm count $\left(1^{6}\right)$ and sperm morphology. Serum testosterone concentration was determined by radioimmunoassay. Although ejaculate volume was greater in captive jaguars ( $n=47$ samples) than in free-living jaguars ( $n=7$ samples) $(P<0.05)$, the free-living jaguars produced more total spermatozoa $\quad\left(59.3 \pm 12.8\right.$ versus $152.0 \pm 88.0 \times 10^{6}$, respectively; not significant) with better viability and forward progression $(2.8 \pm 0.1$ versus $3.5 \pm 0.2$, respectively; $P<0.05)$ and more spermatozoa with normal morphology (73.5 \pm 3.9 versus $50.0 \pm 1.1 \%$, respectively; $P<0.05)$. Serum testosterone concentrations were similar for captive and free-living male jaguars $\left(3.1 \pm 0.7\right.$ and $2.1 \pm 0.8 \mathrm{ng} \mathrm{ml}^{-1}$, respectively). In summary, the data showed that semen may be collected successfully from free-living jaguars and evaluated under field conditions to establish normative reproductive values in this species. The results also indicate that jaguars maintained in zoos show inferior seminal characteristics compared with free-living animals.

\section{Introduction}

The jaguar (Panthera onca), the largest cat of the Americas, is a focal species for conservationists involved in planning and managing neotropical wildlife reserves. Survival requirements for jaguars encompass multiple factors that are also essential for maintaining an ecologically healthy environment (Miller and Rabinowitz, in press). Jaguars have a broad distribution throughout Central and South America (Nowell and Jackson, 1996). In Brazil, the range of jaguars comprises five distinct ecosystems: rainforest, cerrado (savannah), pantanal (wetland), tropical forest and subtropical forest (Oliveira, 1994). Habitat loss and reduction of jaguar populations in several of these ecosystems have been severe (Leite and Boulhosa, in press; Silveira and Jacomo, in press). In 1994, international experts agreed that, by Mace-Lande criteria (Mace and Lande, 1991), jaguar populations were at the critical level in the cerrado, tropical forest and subtropical forest regions (South American Felid Conservation Assessment and Management Plan, 1994).

It is possible that jaguar populations are losing genetic

Email: ronaldo@procarnivoros.org.br diversity and their reproductive potential may be affected as a consequence, as reported for cheetahs (Acinonyx jubatus) (Wildt et al., 1987a), lions (Panthera leo) (Wildt et al., 1987b) and Florida panthers (Roelke et al., 1993). During a recent international meeting of specialists, a comprehensive strategy for jaguar conservation was proposed and it included captive breeding and the use of assisted reproductive techniques to help manage this species genetically (Medellin et al., in press). Captive breeding programmes may be useful for maintaining an insurance population against extinction. However, optimizing captive propagation and ensuring equal founder representation depends on all genetically valuable individuals displaying adequate reproductive function in captivity. In a retrospective survey, the Brazilian Zoological Society observed that only $4 \%$ of the jaguars in captivity have reproduced in the last 10 years (Paz, 2000). However, the reasons for reproductive failure have not been investigated. Information from wild populations is necessary for comparative purposes to assess the normality of reproductive traits in captive animals (Wildt et al., 1987b).

In addition, establishing gene flow between free-living and captive populations may help to maintain adequate genetic heterozygosity. Assisted reproductive techniques, such as 
semen cryopreservation, artificial insemination (AI), in vitro fertilization (IVF) and embryo transfer (ET), can potentially improve genetic exchange between populations, as demonstrated by assisted reproduction in several cat species (Wildt and Roth, 1997). These techniques can also contribute to preserving free-living species through the development of a biological resource bank containing germ plasma, blood products, tissues and DNA (Wildt, 1994). However, information about reproductive characteristics in jaguars and other neotropical felids is extremely limited, and there is no knowledge of reproductive parameters in free-living populations. The objectives of this study were: (i) to examine the seminal and endocrine characteristics of free-living jaguars; and (ii) to compare reproductive characteristics between free-living and captive jaguar populations.

\section{Materials and Methods}

\section{Animals}

All free-living jaguars were captured in accordance with the Brazilian Institute of Environmental Resources (IBAMA) legal requirements (licences 115, 196). Captive jaguars were restrained in accordance with the internal committees of Fundação Parque Zoológico de São Paulo (São Paulo Zoo) and Parque Zoológico Municipal 'Quinzinho de Barros' (Sorocaba Zoo).

\section{Free-living jaguars}

Between October 1995 and June 2000, collection of semen and blood samples was attempted on seven occasions from six free-living jaguars in good body condition. Jaguars were captured, for radiotelemetry studies, using trained hounds $(n=5)$ in the Porto Primavera area (PPP, $22^{\circ} 014^{\prime} \mathrm{S}$ and $\left.53^{\circ} 43^{\prime} \mathrm{W}, n=4\right)$ and Emas National Park (PNE, $18^{\circ} 19^{\prime} \mathrm{S}$ and $52^{\circ} 45^{\prime} \mathrm{W}, n=1$ ). Jaguars were either chased into a tree or cornered on the ground, and then anaesthetized with a combination of tiletamine and zolazepam (10 $\mathrm{mg} \mathrm{kg}^{-1}$ ) (Zoletil 50; Virbac do Brasil, São Paulo, SP) administered via an aluminium dart fired from an air-powered rifle (Cap-chur ${ }^{\circledR}$; Palmer, GE). Anaesthetized animals were captured either by netting while falling from the tree or after achieving lateral recumbency on the ground. On one occasion at Iguaçu National Park (PNI, $25^{\circ} 05^{\prime} \mathrm{S}$ and $53^{\circ} 40^{\prime} \mathrm{W}, n=1$ ), a jaguar was captured in a box-trap using chicken as bait. Mean ( \pm SD) estimated age (months) of jaguars, based on dentition and tooth wear, was $60 \pm 12$.

\section{Captive jaguars}

Male jaguars, all captive-born, were maintained in individual cages at São Paulo Zoo $(n=5)$ or paired with a male or female at the Sorocaba Zoo $(n=3)$. Mean $( \pm$ SD) age (months), based on known dates of birth, was $84 \pm 18$. All animals were fed a meat-based diet (beef with occasional bones but without vitamin or mineral supplementation, or organ meat) and provided with water ad libitum. Chemical restraint was performed using a protocol similar to that described for free-living animals; however, drug injections were administered using a blow dart system. Seven animals were restrained six times and one animal five times, at 2 month intervals.

\section{Testicular volume, blood sample collection, electro- ejaculation and semen evaluation}

After chemical restraint, animals were examined to assess body condition. The testicles were palpated to evaluate consistency (flaccid, normal, turgid) and measurements were made of testicular width and length using callipers. These values of length and width were combined to calculate total testicular volume (Howard et al., 1986). Blood samples were collected between 07:00 and 11:30 h by jugular venepuncture immediately before the onset of electroejaculation. Blood samples were centrifuged ( $800 \mathrm{~g}, 20 \mathrm{~min}$ ) and the recovered sera stored at $-20^{\circ} \mathrm{C}$ until hormone analysis by radioimmunoassay.

Semen was collected using a standardized electroejaculation technique (Wildt et al., 1983). In brief, a rectal probe (diameter $2.6 \mathrm{~cm}$; length $29 \mathrm{~cm}$ ) and portable batteryoperated electrostimulator (AC, $60 \mathrm{~Hz}$ current; Eletrovet Eletronics Equipments, São Paulo, SP) were used to deliver a regimented electroejaculation sequence consisting of a total of 80 stimuli, given in three series of 30, 30 and 20 stimuli with 10 min intervals between series.

Raw semen from each electroejaculation series was evaluated immediately via microscopy ( $\times 200$ magnification) for percentage sperm motility $(0-100 \%)$ and rate of progressive status, on a scale of 0 (no movement) to 5 (rapid forward movement) (Wildt et al., 1983). The ejaculate fractions from each series were pooled and evaluated for total ejaculate volume. For each ejaculate, a sperm motility index (SMI) was calculated to provide an overall evaluation of sperm motility characteristics $(\mathrm{SMI}=$ (percentage $\mathrm{sperm}$ motility + (forward progressive motility $\times 20)) / 2$; Howard et al., 1990). An aliquot of semen was diluted (1:3) in distilled water to determine sperm concentration in a Newbauer chamber. Sperm morphology evaluations were performed by fixing a $100 \mu \mathrm{l}$ aliquot of semen in $200 \mu \mathrm{l}$ of $10 \%$ formalin solution and examining 100-200 individual sperm cells using phase-contrast microscopy $(\times 1000)$ (Wildt et al., 1983). Spermatozoa were classified as normal or as having one of the following abnormalities: macrocephalic; microcephalic; bicephalic; malformed head shape; malformed acrosome; mitochondrial sheath aplasia (including segmental or complete aplasia of the mitochondrial sheath); tightly coiled flagellum; biflagellate; bent flagellum; bent neck; bent mid-piece with or without cytoplasmic droplet; and a proximal or distal cytoplasmic droplet (Johnston et al., 1994).

\section{Radioimmunoassay}

Serum testosterone was analysed by radioimmunoassay using the technique described by Lox et al. (1974) $(n=54$ 
samples; $n=1$ assay). The assay was validated by demonstrating parallelism between dilutions of pooled serum samples and the standard curve $(y=1.12 x+0.6$, $r^{2}=0.99$ ). The sensitivity of the assay was approximately $8.0 \mathrm{pg} \mathrm{ml}^{-1}$, based on $91 \%$ of maximum binding, and the intra-assay coefficient of variation was $<10 \%$. All samples were analysed in duplicate.

\section{Statistical analysis}

Values reported are means \pm SEM. Spearman's correlation analyses were performed to evaluate the relationship between body size, testicular volume, semen characteristics and serum testosterone. The Kruskal-Wallis test was used to assess differences in the reproductive characteristics of the captive and free-living groups.

\section{Results}

The numbers of motile spermatozoa per ejaculate ranged from 0.3 to $291.0 \times 10^{6}$ for captive jaguars, and from 1.5 to $444.0 \times 10^{6}$ for free-living jaguars. Free-living male jaguars showed greater $(P<0.05)$ body weight, testicular volume, sperm progressive status and percentage of normal spermatozoa, whereas captive male jaguars produced a greater $(P<0.05)$ ejaculate volume (Table 1$)$. Normal sperm morphology was positively correlated with testicular volume $(r=0.29 ; P<0.05)$ and negatively correlated with ejaculate volume $(r=-0.34 ; P<0.01)$.

The total proportion of structurally abnormal spermatozoa for the captive and free-living population ranged from 29.0 to $65.0 \%$ and 12.0 to $41.0 \%$, respectively. Overall, for the captive jaguars, $30.0 \pm 0.9 \%$ and $20.0 \pm 0.9 \%$ of the total spermatozoa were classified as primary and secondary pleiomorphic forms, respectively. There was a lower proportion of primary defects in the spermatozoa of the freeliving population $(P<0.05)$ : $10.4 \pm 2.6 \%$ and $16.0 \pm 2.6 \%$ of all spermatozoa were categorized with primary and secondary abnormalities, respectively (Table 2 ).

In the captive group, primary abnormalities predominated, usually in the form of spermatozoa with malformed head shape or tightly coiled flagellum (Fig. 1). In the free-living group, secondary abnormalities predominated, mainly as spermatozoa with a bent flagellum combined with a cytoplasmic droplet. The captive group showed greater $(P<0.05)$ proportions of microcephalic or bicephalic spermatozoa, or spermatozoa with a malformed head or acrosome, a tightly coiled flagellum, or a proximal or distal cytoplasmic droplet (Table 2).

Individual analyses of the semen characteristics of the freeliving jaguars (based on one sample per male) showed lower values for the two youngest animals (approximately 2.5 and 3.5 years old) compared with those in the older free-living jaguars. In the second electroejaculation attempt of the youngest animal (approximately 2.5 years) 4 months later, sperm motility and progressive status appeared to increase from 50.0 to $90.0 \%$ and from 3.0 to 4.0 , respectively.
Serum testosterone concentrations ranged from 0.2 to $9.2 \mathrm{ng} \mathrm{ml}^{-1}$ for captive jaguars and the mean \pm SEM for each animal was $3.5 \pm 0.8 \mathrm{ng} \mathrm{ml}^{-1}(n=6$, range: $1.1-$ $\left.6.6 \mathrm{ng} \mathrm{ml}^{-1}\right), 2.8 \pm 0.6 \mathrm{ng} \mathrm{ml}^{-1}(n=6$, range: $1.4-5.1 \mathrm{ng}$ $\left.\mathrm{ml}^{-1}\right), 2.0 \pm 0.1 \mathrm{ng} \mathrm{ml}^{-1}\left(n=6\right.$, range: $\left.1.7-2.4 \mathrm{ng} \mathrm{ml}^{-1}\right), 2.0$ $\pm 0.3 \mathrm{ng} \mathrm{ml}^{-1}\left(n=6\right.$, range: $\left.1.2-3.6 \mathrm{ng} \mathrm{ml}^{-1}\right), 2.9 \pm 0.6 \mathrm{ng}$ $\mathrm{ml}^{-1}\left(n=6\right.$, range: $\left.1.5-5.2 \mathrm{ng} \mathrm{ml}^{-1}\right), 7.8 \pm 0.5 \mathrm{ng} \mathrm{ml}^{-1}(n=$ 6, range: $\left.5.9-9.2 \mathrm{ng} \mathrm{ml}^{-1}\right), 1.2 \pm 0.3 \mathrm{ng} \mathrm{ml}^{-1}(n=6$, range: $\left.0.2-2.5 \mathrm{ng} \mathrm{ml}^{-1}\right)$ and $2.3 \pm 0.4 \mathrm{ng} \mathrm{ml}^{-1}(n=5$, range: 1.4-3.5 $\mathrm{ng} \mathrm{m}^{-1}$ ). Serum testosterone concentrations ranged from 0.1 to $5.9 \mathrm{ng} \mathrm{ml}^{-1}$ for free-living jaguars. The average value was similar for captive and free-living jaguars (Table 1).

\section{Discussion}

The results of this study represent the first detailed information on reproductive endocrine characteristics reported for any free-living neotropical felid. The inherent difficulties in collecting physiological data from free-living jaguars are reflected in the small number of samples, representing capture opportunities over a 5 year period for three jaguar radio-tracking projects at different sites in Brazil. Physical capture of free-living jaguars was the major barrier to data acquisition, owing to the remoteness and inaccessibility of remaining jaguar habitat, low jaguar population densities, broad territorial ranges, and the secretive and nocturnal nature of the species (Miller and Rabinowitz, in press). Given these obstacles, if establishing a biological resource bank is a priority for jaguar conservation efforts, it is imperative that biological collection (including semen) is maximized during each capture opportunity.

Semen analyses of free-living jaguars may be useful for assessing the reproductive and genetic health of an individual animal or, in some cases, a population. In particular, a high percentage of pleiomorphic spermatozoa in ejaculates has been associated with low genetic variability in several felid species (Wildt et al., 1983, 1987b; Roelke et al., 1993; Barone et al., 1994). In this study, all free-living jaguars had low percentages (range 12-41\%) of morphologically abnormal spermatozoa (compared with other free-living cat species), providing one positive indicator of adequate genetic variation in the sampled animals. This observation concurs with those of Johnson et al. (in press) who suggested that, in general, reduced heterogeneity does not threaten the future viability of jaguars. However, a decreasing genetic variability has been found in the Porto Primavera area (Eizirik et al., 2001). Abrupt population declines in Iguaçu National Park and Emas National Park may have been too recent to observe evidence of inbreeding, loss of genetic diversity or decreased reproductive potential, similar to that documented in Florida panther populations under similar constraints (Roelke et al., 1993). From a conservation perspective, continued monitoring of reproductive and genetic parameters in free-living jaguars may be valuable 
Table 1. Mean ( \pm sem) values for body weight, testicular volume, semen characteristics and serum testosterone for captive $(n=8)$ and free-living $(n=6)$ male jaguars (Panthera onca)

\begin{tabular}{|c|c|c|}
\hline Characteristics & $\begin{array}{c}\text { Captive } \\
(n=47 \text { samples })\end{array}$ & $\begin{array}{c}\text { Free-living } \\
(n=7 \text { samples })\end{array}$ \\
\hline Body weight $(\mathrm{kg})$ & $72.0 \pm 11.0^{\mathrm{a}}$ & $96.0 \pm 7.7^{b}$ \\
\hline Testicular volume $\left(\mathrm{cm}^{3}\right)$ & $41.6 \pm 0.6^{\mathrm{a}}$ & $52.4 \pm 3.4^{b}$ \\
\hline Testicular volume/body weight $\left(\mathrm{cm}^{3} \mathrm{~kg}^{-1}\right)$ & $0.6 \pm 0.0$ & $0.5 \pm 0.0$ \\
\hline Ejaculate volume (ml) & $8.3 \pm 0.7^{\mathrm{a}}$ & $4.1 \pm 0.7^{b}$ \\
\hline Sperm concentration $\left(\times 10^{6} \mathrm{ml}^{-1}\right)$ & $8.0 \pm 1.7$ & $35.0 \pm 21.3$ \\
\hline Total spermatozoa/ejaculate $\left(\times 10^{6}\right)$ & $59.3 \pm 12.8$ & $152.0 \pm 88.0$ \\
\hline Sperm motility $(\%)$ & $64.0 \pm 2.4$ & $73.0 \pm 6.1$ \\
\hline Rate of progressive status $(0-5)^{*}$ & $2.8 \pm 0.1^{\mathrm{a}}$ & $3.5 \pm 0.2^{b}$ \\
\hline Sperm motility index ${ }^{\dagger}$ & $61.0 \pm 2.2$ & $72.0 \pm 5.0$ \\
\hline Total motile spermatozoa/ejaculate $\left(\times 10^{6}\right)$ & $42.8 \pm 10.5$ & $108.7 \pm 65.4$ \\
\hline Total spermatozoa/testicular volume $\left(10^{6} \mathrm{~cm}^{-3}\right)$ & $1.4 \pm 0.3$ & $2.9 \pm 1.6$ \\
\hline Serum testosterone $\left(\mathrm{ng} \mathrm{m}^{-1}\right)$ & $3.1 \pm 0.7$ & $2.1 \pm 0.8$ \\
\hline
\end{tabular}

*Rate of progressive status on a scale of 0 (no movement) to 5 (rapid forward movement).

tSperm motility index $=($ motility $+(20 \times$ vigour $)) / 2$

abValues within rows with different superscripts are significantly different $(P<0.05)$.

Table 2. Structural morphology (\%) of spermatozoa from captive and free-living male jaguars (Panthera onca)

\begin{tabular}{lcc}
\hline & Captive & Free-living \\
\hline Normal & & $73.5 \pm 3.9^{\mathrm{b}}$ \\
Abnormal & & \\
Primary & $30.0 \pm 0.9^{\mathrm{a}}$ & $10.0 \pm 2.6^{\mathrm{b}}$ \\
Macrocephalic & $0.4 \pm 0.1$ & $0.3 \pm 0.2$ \\
Microcephalic & $1.0 \pm 0.1^{\mathrm{a}}$ & $0.0^{\mathrm{b}}$ \\
Bicephalic & $1.4 \pm 0.2^{\mathrm{a}}$ & $0.0^{\mathrm{b}}$ \\
Malformed head shape & $13.3 \pm 0.7^{\mathrm{a}}$ & $4.0 \pm 1.9^{\mathrm{b}}$ \\
Malformed acrosome & $4.5 \pm 0.4^{\mathrm{a}}$ & $1.1 \pm 0.4^{\mathrm{b}}$ \\
Abnormal mitochondrial sheath & $1.8 \pm 0.3$ & $1.1 \pm 0.4$ \\
Tightly coiled flagellum & $7.5 \pm 0.6^{\mathrm{a}}$ & $3.7 \pm 0.9^{\mathrm{b}}$ \\
Biflagellate & $0.4 \pm 0.1$ & 0.0 \\
Secondary & $20.0 \pm 0.9$ & $16.0 \pm 2.6$ \\
Bent mid-piece with cytoplasmic droplet & $2.2 \pm 0.3$ & $2.0 \pm 0.7$ \\
Bent mid-piece without cytoplasmic droplet & $3.2 \pm 0.3$ & $3.0 \pm 1.1$ \\
Bent flagellum with cytoplasmic droplet & $2.2 \pm 0.3$ & $1.4 \pm 0.7$ \\
Bent flagellum without cytoplasmic droplet & $4.1 \pm 0.4$ & $7.1 \pm 1.5$ \\
Distal cytoplasmic droplet & $3.0 \pm 0.3^{\mathrm{a}}$ & $0.4 \pm 0.4^{\mathrm{b}}$ \\
Proximal cytoplasmic droplet & $4.1 \pm 0.4^{\mathrm{a}}$ & $1.7 \pm 0.7^{\mathrm{b}}$ \\
Bent neck & $1.0 \pm 0.1$ & $0.3 \pm 0.2$ \\
\hline
\end{tabular}

${ }^{a b}$ Values within rows with different superscripts are significantly different $(P<0.05)$.

for developing strategies to preserve natural dispersal corridors and maintain adequate gene flow and genetic diversity.

Information from reproductive endocrine assessments of free-living animals may be useful for evaluating the influence of captivity on reproductive function (Wildt et al., 1987b). Semen characteristics of captive jaguars have been described by Swanson et al. (1995) and Morato et al. (1998) and are similar to those reported for captive jaguars in the present study. However, in comparison with free-living jaguars, ejaculate traits of captive jaguars were generally inferior. Spermatozoa from captive jaguars had lower $(P<$ $0.05)$ rates of progressive status and percentages of normal sperm morphology. Although not statistically significant, captive jaguars also tended to have lower values for sperm concentration and progressive motility.

Considerable numbers of spermatozoa from captive jaguars were afflicted with primary abnormalities, which 

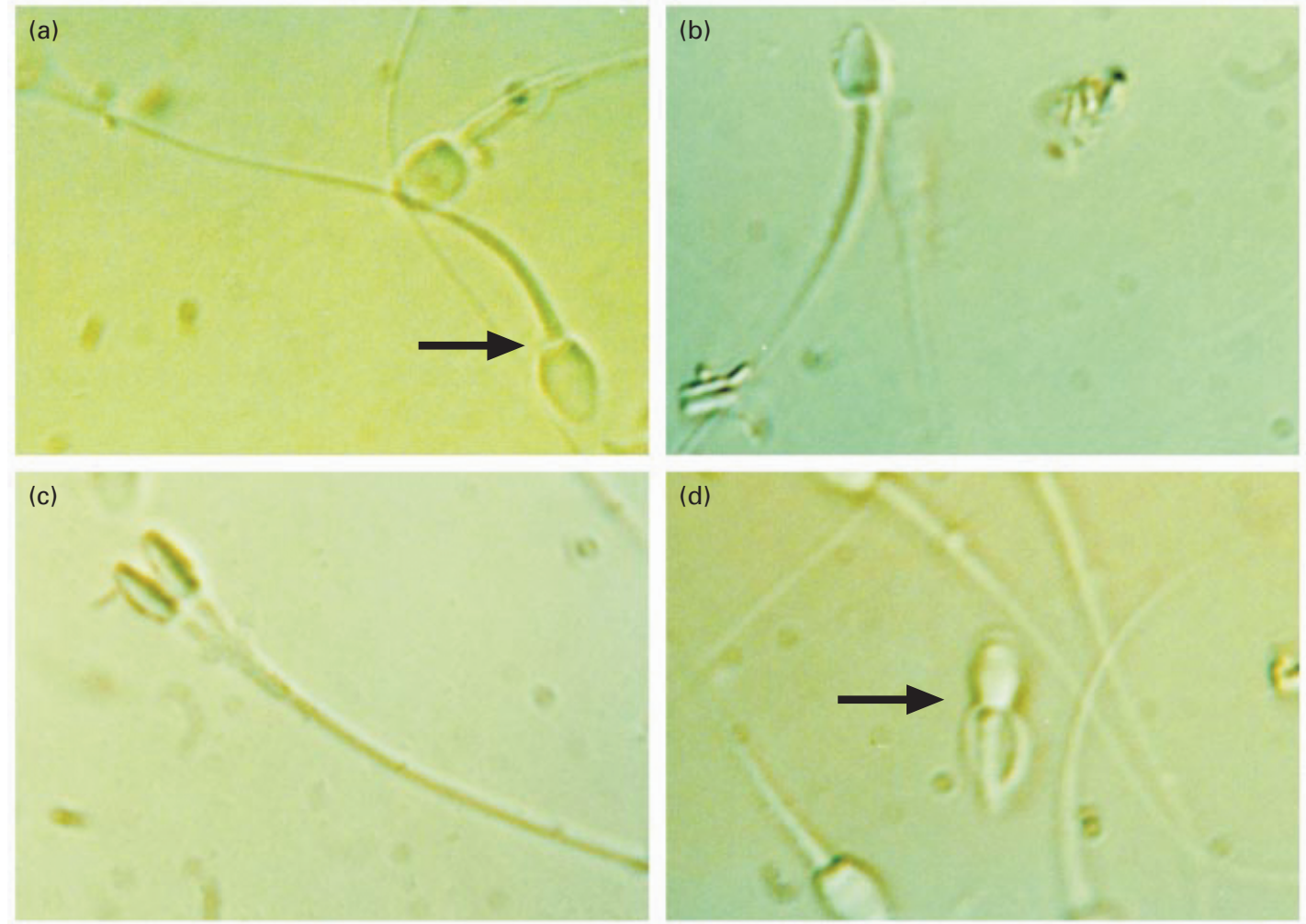

Fig. 1. Morphology of jaguar (Panthera onca) spermatozoa. (a) Normal morphology; (b) malformed head shape; (c) biflagellate; (d) tightly coiled flagellum.

are often associated with spermatogenic dysfunction (Wildt et al., 1987b). Sperm morphology parameters reported to be associated with decreased fertility are used commonly as the first step in evaluation of male fertility, and individuals with abnormally high values in one or more parameters are considered to be of questionable fertility (Rogers, 1985). Increasing numbers of morphologically abnormal spermatozoa have been reported to decrease fertility in humans (Donnelly et al., 1998), cattle (Saacke et al., 1968), horses (Bader et al., 1988), pigs (Larsson et al., 1980), sheep (Hulet et al., 1965), laboratory rodents (Burkhart and Malling, 1981) and domestic cats (Howard et al., 1991).

The findings from the present study indicate that further research is needed to understand the relationship between semen characteristics and endocrine profiles in jaguars. Despite the inferior seminal traits of the captive jaguars, serum testosterone concentrations were found to be similar between captive and free-living jaguars. In contrast, higher proportions of structurally abnormal spermatozoa in domestic cats are related to gonadal insufficiency in testosterone production (Howard et al., 1990).

Collectively, the data from the present study indicate that captive jaguars have a lower reproductive potential than free-living jaguars. As captive populations in zoos provide insurance against extinction, it is imperative that all genet- ically valuable individuals are able to propagate within a managed breeding programme. It is important to determine the cause of suboptimal reproductive traits observed in captive jaguars, to achieve this goal. In general, three primary factors have direct effects on semen characteristics: nutrition, environment and genetics (Barth and Oko, 1989). These factors, alone or in combination, may be affecting the semen traits in the captive jaguar population used in this study. Swanson et al. (1995) conducted reproductive evaluations on 186 males of eight neotropical cat species, including jaguars, housed in Latin American zoos, and observed inferior semen parameters compared with conspecifics housed in North American zoos. It was suggested that nutritionally inadequate diets in Latin American zoos were at least partially responsible for these differences. Paz (2000) demonstrated that vitamin and mineral supplementation of a meat-based diet reduced the percentage of primary defects in ejaculates of captive jaguars; however, no difference was found in the total percentage of abnormal spermatozoa.

There is only limited scientific information on environmental factors affecting reproduction in large cat species. In a study of captive jaguars in Brazilian zoos, it was observed that season did not affect semen quantity and quality (Morato et al., 1999). In addition, temperature and humidity did not affect the endocrine testicular function in captive male jaguars (Morato, 2001). 
There is evidence that reproductive parameters are compromised by inbreeding (Wildt, 1994). As most (approximately $92 \%$ ) of the jaguars maintained in Brazilian zoos were born in captivity and have undefined pedigrees (Morato and Gasparini, 1994), it is possible that inbreeding is adversely affecting reproductive traits. Further studies are needed to address the genetic relatedness of captive jaguars and to assess potential inbreeding effects among the captive population.

The findings of this study are also relevant to another aspect of jaguar conservation, the application of assisted reproduction for genetic management. Assisted reproductive techniques, such as AI, IVF-ET and sperm cryopreservation, have potential as an adjunct to natural breeding for managing captive populations, but may also be useful in facilitating gene flow between in situ and ex situ populations (IUDZ and CBSG, 1993). In the past few years, assisted reproductive techniques have been used to produce offspring in several non-domestic cat species (Wildt and Roth, 1997), including cheetahs after Al with frozen-thawed spermatozoa collected from free-living males in Africa (Howard et al., 1997). The present study has demonstrated that high quality semen may be collected from free-living jaguars, a necessary first step for cryopreservation of jaguar spermatozoa in the field. In the near future, establishing gene flow between free-living and captive jaguars may be possible through Al with frozen-thawed spermatozoa or by incorporation of this resource into the ongoing IVF-ET studies in jaguars (Morato et al., 2000).

In summary, the findings of the present study have shown that semen may be collected successfully from free-living jaguars and evaluated under field conditions to establish normative reproductive values in this species. The results also indicate that jaguars maintained in zoos show inferior seminal characteristics compared with free-living animals. Finally, the results of this research have furthered the potential application of semen collection and cryopreservation in free-living jaguars as one approach for promoting gene flow between in situ and ex situ populations.

The authors would like to thank Parque Zoológico Municipal de Sorocaba-SP, Fundação Parque Zoológico de São Paulo and Instituto Brasileiro de Meio Ambiente e Recursos Naturais (IBAMA) who permitted the use of the animals included in this study. The authors thank the Pro-Carnivoros Association staff who were responsible for capturing free-living jaguars. They are also grateful to Idea T. N. Verreschi and Ivone I. Bianchi from the Endocrinology Laboratory of the Escola Paulista de Medicina UNIFESP for the hormone analyses. They also thank William Swanson, Elizabeth Crichton and two anonymous reviewers for their helpful comments and suggestions. This study was supported by Fundação de Amparo à Pesquisa do Estado de São Paulo (grants nos 97/02051-7 and 97/09160-6) and Companhia Energética do Estado de São Paulo.

\section{References}

Bader H, Hoppen HO, Wockener A and Merkt H (1988) Case studies in stallions with fertility problems: endocrine and spermatological aspects Proceedings of International Congress on Animal Reproduction and Artificial Insemination 3367 (Abstract)
Barone MA, Roelke ME, Howard JG, Brown JL, Anderson AE and Wildt DE (1994) Reproductive characteristics of male Florida panthers; comparative studies from Florida, Texas, Colorado, Latin America, and North American zoos Journal of Mammalogy 75 150-162

Barth AD and Oko RJ (1989) Abnormal Morphology of Bovine Spermatozoa lowa State University Press, Ames

Burkhart JG and Malling HV (1981) Sperm abnormalities in the PL/J mouse strain: a description and proposed mechanism for malformation Gamete Research 4 171-183

Donnelly ET, Lewis SEM, McNally JA and Thompson W (1998) In vitro fertilization and pregnancy rates: the influence of sperm motility and morphology on IVF outcome Fertility and Sterility 70 305-314

Eizirik E, Kim JH, Menotti-Raymond M, Crawshaw PG, Jr, O'Brien SJ and Johnson WE (2001) Phylogeography, population history and conservation genetics of jaguars (Panthera onca, Mammalia, Felidae) Molecular Ecology 10 67-79

Howard JG, Bush M and Wildt DE (1986) Semen collection, analysis and cryopreservation in non-domestic mammals. In Current Therapy in Theriogenology pp 1047-1053 Ed. D Morrow. WB Saunders, Philadelphia

Howard JG, Brown JL, Bush M and Wildt DE (1990) Teratospermic and normospermic domestic cats: ejaculate traits, pituitary-gonadal hormones, and improvement of sperm motility and morphology after swim-up processing Journal of Andrology 11 204-215

Howard JG, Bush M and Wildt DE (1991) Teratospermia in domestic cats compromises penetration of zona-free hamster ova and cat zonae pellucidae Journal of Andrology 12 36-45

Howard JG, Roth TL, Swanson WF, Buff JL, Bush M, Grisham J, MarkerKraus, Kraus D and Wildt DE (1997) Successful intercontinental genome resource banking and artificial insemination with cryopreserved sperm in cheetahs Journal of Andrology 5553

Hulet CV, Foose WC and Blackwell RL (1965) Relationship of semen quality and fertility in the ram to fecundity in the ewe Journal of Reproduction and Fertility $9311-341$

IUDZ and CBSG (1993) The World Zoo Conservation Strategy: The Role of the Zoos and Aquaria of the World in Global Conservation Chicago Zoological Society, Illinois

Johnson WE, Eizirik E and $\mathbf{O}^{\prime}$ Brien Jaguar evolution and population genetics. In El Jaguar en el Nuevo Milenio. Una Evaluacion de su Estado, Deteccion de Prioridades y Recomendaciones para la Conservacion de los Jaguares en America Eds RA Medellin, C Chetkiewicz, A Rabinowitz, KH Redford, JG Robinson, E Sanderson and A Taber, Universidad Nacional Autonoma de Mexico/Wildlife Conservation Society, Mexico DF (in press)

Johnston LA, Armstrong DL and Brown JL (1994) Seasonal effects on seminal and endocrine traits in the captive snow leopard (Panthera uncia). Journal of Reproduction and Fertility 102 229-236

Larsson K, Darenius K and Johansson K (1980) Sperm morphology and in vitro viability in diluted semen in relation to fertility of Al boars Nordwen Veterinaermed 32 533-535

Leite RP and Boulhosa RLP Ecology and conservation of jaguars in the Atlantic Rainforest of Brazil. In El Jaguar en el Nuevo Milenio. Una Evaluacion de su Estado, Deteccion de Prioridades y Recomendaciones para la Conservacion de los Jaguares en America Eds RA Medellin, C Chetkiewicz, A Rabinowitz, KH Redford, JG Robinson, E Sanderson and A Taber, Universidad Nacional Autonoma de Mexico/Wildlife Conservation Society, Mexico DF (in press)

Lox CD, Christian CD and Heine MW (1974) A simple radioimmunoassay for testosterone American Journal of Obstetrics and Gynecology 118 $114-118$

Mace GM and Lande R (1991) Assessing extinction threats: toward a reevaluation of IUCN threatened species categories Conservation Biology 5 148-157

Medellin RA, Chetkiewicz C, Rabinowitz A, Redford KH, Robinson JG, Sanderson E and Taber A In El Jaguar en el Nuevo Milenio. Una Evaluacion de su Estado, Deteccion de Prioridades y Recomendaciones para la Conservacion de los Jaguares en America Eds RA Medellin, C Chetkiewicz, A Rabinowitz, KH Redford, JG Robinson, E Sanderson and A Taber, Universidad Nacional Autonoma de Mexico/Wildlife Conservation Society, Mexico DF (in press) 
Miller B and Rabinowitz A Why conserve jaguars? In El Jaguar en el Nuevo Milenio. Una Evaluacion de su Estado, Deteccion de Prioridades y Recomendaciones para la Conservacion de los Jaguares en America Eds RA Medellin, C Chetkiewicz, A Rabinowitz, KH Redford, JG Robinson, E Sanderson and A Taber, Universidad Nacional Autonoma de Mexico/Wildlife Conservation Society, Mexico DF (in press)

Morato RG (2001) Reprodução assistida como ferramenta auxiliar no manejo e conservação da onça pintada (Panthera onca) Doctoral Thesis, Universidade de São Paulo, São Paulo

Morato RG and Gasparini RL (1994) Levantamento preliminar sobre a situação da onça-pintada (Panthera onca) em cativeiro XVIII Congresso da Sociedade de Zoológicos do Brasil 1321

Morato RG, Guimarães MABV, Nunes ALV, Carciofi AC, Ferreira F, Barnabe VH and Barnabe RC (1998) Semen collection and evaluation in the jaguar Brazilian Journal of Veterinary Research and Animal Science 35 178-181

Morato RG, Guimarães MABV, Ferreira F, Verreschi ITN and Barnabe RC (1999) Reproductive characteristics of captive male jaguars (Panthera onca). Brazilian Journal of Veterinary Research and Animal Science $\mathbf{3 6}$ www.scielo.br/bjvras (6 October 2000)

Morato RG, Crichton EG, Paz RCR et al. (2000) Ovarian stimulation and successful in vitro fertilization in the jaguar (Panthera onca). Theriogenology 53339

Nowell K and Jackson P (1996) Wild Cats: Status Survey and Conservation Action Plan Gland, IUCN (World Conservation Union)

Oliveira TG (1994) Neotropical Cats: Ecology and Conservation Edusma, São Luís, Brasil

Paz RCR (2000) Influência nutricional sobre a produção e qualidade do sêmen de onças pintadas (Panthera onca) mantidas em cativeiro Master's Thesis, Universidade de São Paulo, São Paulo

Raals K, Brugger K and Ballou J (1979) Inbreeding and juvenile mortality in small populations of ungulates Science 206 1101-1103

Roelke ME, Martenson JS and O'Brien SJ (1993) The consequences of demographic reduction and genetic depletion in the endangered Florida panther Current Biology 3 340-350

Rogers BJ (1985) The sperm penetration assay: its usefulness re-evaluated Fertility and Sterility $\mathbf{4 3}$ 821-839

Saacke RG, Amann RR and Marshall CE (1968) Acrosomal cap abnormalities of sperm from subfertile bulls Journal of Animal Science 27 1391-1400

Silveira $\mathbf{L}$ and Jácomo ATA Jaguar conservation in the Cerrado. In El Jaguar en el Nuevo Milenio. Una Evaluacion de su Estado, Deteccion de Prioridades y Recomendaciones para la Conservacion de los Jaguares en America Eds RA Medellin, C Chetkiewicz, A Rabinowitz, KH Redford, JG Robinson, E Sanderson and A Taber, Universidad Nacional Autonoma de Mexico/Wildlife Conservation Society, Mexico DF (in press)

South American Felid Conservation Assessmant and Management Plan (1994) Meeting São Paulo, Brasil

Swanson WF, Wildt DE, Cambre RC et al. (1995) Reproductive survey of endemic felid species in Latin American zoos: male reproductive status and implications for conservation. In American Association of Zoo and Veterinarians Annual Meeting pp 374-380

Wildt DE (1994) Endangered species spermatozoa: diversity, research and conservation. In Function of Somatic Cells in the Testis pp 1-24 Ed. A Bartke. Springer, New York

Wildt DE and Roth TL (1997) Assisted reproduction for managing and conserving threatened felids International Zoo Yearbook 35 164-172

Wildt DE, Bush M, Howard JG, O'Brien SJ, Meltzer D, Van Dyk A, Ebedes H and Brand DJ (1983) Unique seminal quality in the South African cheetah and a comparative evaluation in the domestic cat Biology of Reproduction 29 1019-1025

Wildt DE, O'Brien SJ, Howard JG, Caro TM, Roelke ME, Brown JL and Bush M (1987a) Similarity in ejaculate-endocrine characteristics in captive versus free-ranging cheetahs of two subspecies Biology of Reproduction $36351-360$

Wildt DE, Bush M, Goodrowe KL, Packer C, Pusey AE, Brown IL, Joslin P and O'Brien SJ (1987b) Reproductive and genetic consequences of founding isolated lion populations Nature 329 328-331

Received 24 April 2001.

First decision 24 May 2001.

Accepted 27 July 2001. 